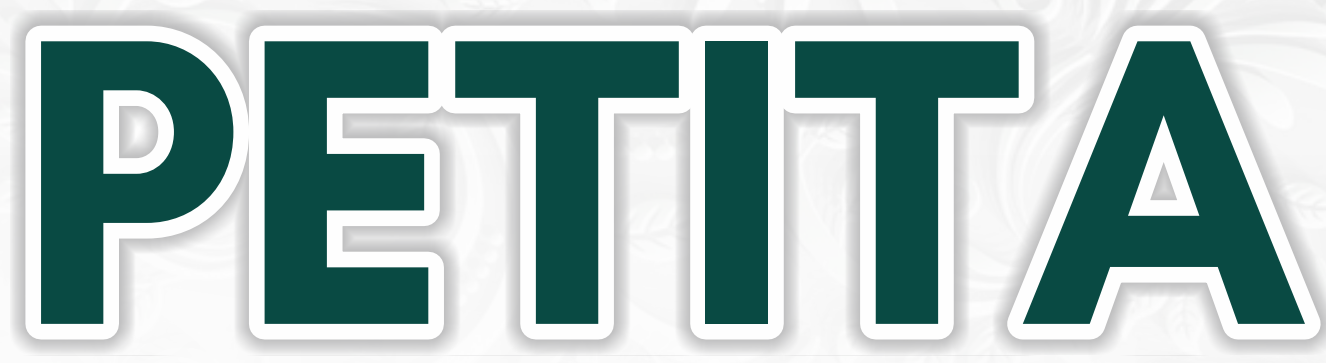

Jurnal Kajian Ilmu Hukum dan Syariah

Published By:

Lembaga Kajian Konstitusi Indonesia (LKKI)

Fakultas Syariah dan Hukum Universitas Islam Negeri (UIN) Ar-Raniry Banda Aceh Jl. Syeikh Abdul Rauf, Kopelma Darussalam Banda Aceh, Telp: 0651-7557442 Website: http://petita.ar-raniry.ac.id 


\section{Contents}

EKSISTENSI BITCOIN DALAM PERSPEKTIF MAQĀṢID AL-SYAR'ĪYAH

(Dara Lidia, Jabbar Sabil \& Syarifuddin Usman / 104-113)

TATACARA PENETAPAN BATAS TANAH DIKALANGAN MASYARAKAT KECAMATAN BAKONGAN TIMUR DITINJAU MENURUT KONSEP MAL 'UQAR

(Elida Gusmira, Saifuddin Sa'dan \& Faisal Fauzan / 114-127)

TINJAUAN HUKUM ISLAM TERHADAP SISTEM PENYELESAIAN WANPRESTASI PRODUK ARRUM DI PEGADAIAN SYARIAH ACEH BESAR

(Asdi Marni, Edi Darmawijaya \& Faisal Fauzan / 128-136)

SANKSI ADAT BAGI PELAKU KEKERASAN FISIK DITINJAU MENURUT HUKUM PIDANA ISLAM (Studi Terhadap Adat Kampung Taman Firdaus, Kecamatan Pintu Rime Gayo, Kabupaten Bener Meriah)

(Abdul Rahman, Jamhuri \& Irwansyah / 137-144)

DAMPAK PEMEKARAN DAERAH PADA PELAYANAN PUBLIK DITINJAU MENURUT SISTEM HUKUM INDONESIA

(Ali Abubakar, Sitti Mawar \& Nurdin Syah / 145-155)

MARK UP PENJUALAN HARGA TIKET BUS PADA LOKET TERMINAL BATOH DALAM PERSPEKTIF TAS'IR AL-JABAR (Studi tentang Penyimpangan Harga Dari Ketetapan Organda Banda Aceh)

(Aris Rahmaddillah / 156-169)

PROSES PENIMBANGAN IKAN DI TEMPAT PELELANGAN IKAN LAMPULO KOTA BANDA ACEH DALAM PERSPEKTIF MA'QUD 'ALAIH

(Alfata / 170-175)

SANKSI BAGI PELAKU ZINA (Perbandingan Qanun No. 6 Tahun 2014 Dan Enakmen Jenayah Syariah Negeri Selangor No. 9 Tahun 1995 Seksyen 25)

(Ali Abubakar, Badrul Munir \& Cempaka Sari Harahap / 176-200) 
PETITA: Jurnal Kajian Ilmu Hukum dan Syariah

Volume 3, Number 2, 2018

P-ISSN: 2502-8006 E-ISSN: 2549-8274

DOI: https://doi.org/10.22373/petita.v3i2.53

\title{
PROSES PENIMBANGAN IKAN DI TEMPAT PELELANGAN IKAN LAMPULO KOTA BANDA ACEH DALAM PERSPEKTIF MA'QUD 'ALAIH
}

\author{
ALFATA \\ Fakultas Syariah dan Hukum \\ Universitas Islam Negeri Ar-Raniry Banda Aceh \\ Email: alfataosgo@gmail.com
}

\begin{abstract}
Fish Auction Place (TPI) in Lampulo, Banda Aceh, is the largest place of loading and unloading fish in Aceh. However, it has not succeeded in providing the best service to consumers. The accuracy of the scales used by traders is often unclear in weighing fish so that consumers are disadvantaged. The results of the study revealed that the process of weighing fish in TPI Lampulo was inaccurate in term of the scale measurement, and rounding of the scales had been practiced to gain more benefits for the traders yet disadvantages the consumers. Furthermore, the fish traders who sell fish in large quantities do not pay attention to the containers when weighing. Fish weighing containers are sometimes wet or dry, a dry container weighing approximately 2.8 kilograms or 3 kilograms for the wet one. The fish traders in TPI lampulo Banda Aceh rounded the weight to 3 kilograms, meaning 0.2 kilograms of loss for consumers. According to some traders, it had become customary. It can be concluded that the process of weighing the fish at TPI Lampulo Banda Aceh was not accurate in term of measuring the scales.
\end{abstract}

Keywords: Process, Scales, TPI, Ma'qud ‘Alaih

\begin{abstract}
Abstrak:Tempat Pelelangan Ikan di Lampulo Kota Banda Aceh, merupakan tempat yang terbesar di Aceh dimana bongkar muat ikan, namum dengan begitu belum bisa memberikan pelayanan yang terbaik kepada konsumen, pedagang dalam menimbang ikan belum jelas keakuratan timbangan sehingga konsumen merasa dirugikan. Adapun tujuan penelitian penulis adalah untuk mengetahui bagaimana proses penimbangan ikan dalam perspektif ma'qud alaih di tempat pelelangan ikan di Kota Banda Aceh. Untuk mencapai tujuan penelitian maka penulis menggunakan metode analisis deskriptif dengan pendekatan Kualitatif. Data yang dikumpulkan melalui Library research dan Field research seperti : wawancara, observasi dan dokumentasi. Jenis penelitian ini yang menunjukan bahwa pemecahan permasalahan yang aktual dengan jalan menyusun, menganalisa, dan menginterprestasis seluruh data yang berhubungan dengan penulisan. Dari hasil penelitian ditemukan proses penimbangan ikan di TPI Lampulo tidak akurat takaran timbangannya, dan pembulatan ukuran timbangan sudah menjadi kebiasaan demi mendapatkan keuntungan bagi pedagang yang merugikan konsumen, para pedagang ikan yang menjual ikan dalam jumlah yang banyak ketika melakukan penimbangan tidak memperhatikan wadah tempat penimbangan ikan. Wadah tempat penimbangan ikan kadang kala basah atau kering. Terdapat perbedaan berat wadah yang kering mencapai 2,8 kilogram ketika basah wadah tersebut mencapai 3 kilogram. Para pedagang ikan di TPI lampulo Kota Banda Aceh membulatkan menjadi 3 kilogram terdapat 0,2 kilogram kerugian bagi konsumen. Menurut beberapa pedagang hal tersebut sudah menjadi kebiasan. Berdasarkan uraian di atas dapat disimpulkan bahwa proses penimbangan ikan yang tejadi di TPI Lampulo Banda Aceh tidak akurat takaran timbangan, menurut tinjaun ma'qud 'alaih penimbang ikan yang terjadi di TPI Lampulo belum sah, karena belum terpenuhi syarat keakuratan timbangan.
\end{abstract}

Kata kunci: Proses, Timbangan, TPI, Ma’qud ‘Alaih. 


\section{PENDAHULUAN}

Islam membolehkan umatnya berusaha mencari rezeki melalui jalan perniagaan (jual beli) tetapi dengan syarat tidak boleh menyimpang menurut ketentuan-ketentuan Islam. Menurut Yusuf al-Qardhawi jual beli yang benar harus dapat berfungsi sebagai sarana untuk membentuk persaudaraan yang kuat dalam islam dan mampu menciptakan kestabilan serta ketertiban. ${ }^{1}$

Dalam Islam, aktivitas jual beli selain sebagai sarana untuk mendapat profit karena dikategorikan sebagai akad tijarah, juga mengandung nilai sosial dan ibadah meskipun bukan ibadan kategori "ibadah mahdhah" karena akad ini dapat menjadi sarana tolong menolong antar sesama manusia untuk memenuhi kebutuhan hidup.

Dari hasil wawancara yang dilakukan dengan beberapa pedagang ikan di TPI Lampulo, ditemukan bahwa para pedagang seringkali melakukan praktik pembulatan ukuran timbangan ketika melakukan penimbangan ikan. Terjadinya hal semacam ini dikarenakan kurangnya perhatian dari pihak pengelola TPI untuk melakukan survei terhadap keakuratan takaran timbangan para pedagang. ${ }^{2}$ Sebagai contoh ketika seorang konsumen membeli ikan dengan takaran 25 kilogram setelah ditimbang kembali ternyata beratnya kurang dari 25 kilogram. Hal ini disebabkan oleh media penimbangan dan wadah tempat penimbangan yang tidak akurat. Dengan demikian ketika masyarakat membeli dalam jumlah yang besar ada potensi terjadi kerugian banyak. Terlebih lagi ketika pedagang melakukan penimbangan tidak melihat wadah penimbangan apakah basah atau kering mereka langsung melakukan penimbangan. Maka terjadilah ketidak akuratan timbangan. Dari berat wadah hanya 2,8 kilogram di bulatkan menjadi 3 kilogram, maka terdapat sebanyak 0,2 kilogram kerugian konsumen. ${ }^{3}$

Pembulatan ukuran timbangan menurut beberapa pedagang sudah menjadi kebiasan di TPI Lampulo tersebut, meski banyak keuntungan bagi pedagang dan merugikan konsumen. Pandangan konsumen dalam hal pembulatan ukuran timbangan ini sangat bervariasi dan tergantung cara pandangnya. ${ }^{4}$

Jika hubungkan dengan perekonomian dalam Islam maka ada empat nilai utama dalam bermuamalah, yaitu ketuhanan (rabbaniyyah), akhlak, kemanusiaan dan pertengahan. Nilai-nilai ini menggambarkan kekhasan (keunikan) yang utama bagi ekonomi Islam. Bahkan dalam kenyataannya nilai-nilai ini merupakan kekhasan yang bersifat menyeluruh yang tampak jelas pada segala sesuatu yang berlandaskan ajaranIslam. ${ }^{5}$

Dalam penelitian ini, penulis menggunakan metode kualitatif dengan analisis deskriptif, yaitu penelitian yang memanfaatkan wawancara terbuka untuk menelaah dan memahami sikap, pandangan, perasaan dan perilaku individu atau sekelompok orang. ${ }^{6}$ Dalam mengumpulkan data yang terkait dengan objek penelitian, penulis mengambil dari dua jenis penelitian yaitu data yang diperoleh dari library research (penelitianke pustakaan) dan Field research (penelitian lapangan).

$1 \quad$ Yusuf al-Qardhawi, Norma Dan Etika Ekonomi Islam (Gema Insani Press 1997), hlm. 173.

2 'Hasil Wawancara Dengan Nurdin, Pedagang Ikan Di TPI Lampulo Banda Aceh Pada Tangal 20 November 2017'.

3 'Hasil Wawancara Dengan Ridwan, Pedagang Ikan Di TPI Lampulo Banda Aceh Pada Tangal 20 November 2017'.

4 'Hasil Wawancara Dengan Saifudin Dan Samsul, Pedagang Ikan Di TPI Lampulo Banda Aceh Pada Tanggal 20 November 2017'.

5 Yusuf al-Qardhawi (n 1), hlm. 23.

6 J. Moleong, Metodelogi Penelitian Kualitatif(PT Remaja Rosdakarya 2006), hlm. 5. 


\section{PEMBAHASAN}

\section{Pengertian Ma'qud 'Alaih}

Ma'qud 'alaih secara umum bermakna harta yang dikeluarkan dari kedua pelaku akad, salah satu harta tersebut dinamakan barang dagangan yang lainya disebut harga. Para fuqaha sepakat bahwa jual beli sah jika ma'qud 'alaih-nya berbentuk harta yang bernilai, tertentu, ada, dan dapat diserahkan, bisa diketahui oleh kedua pelaku akad, tidak berkaitan dengan hak orang lain, dan tidak dilarang oleh syara'?

Ma'qud 'Alaih adalah objek akad atau benda-benda yang dijadikan akad yang bentuknya tampak dan membekas. Barang tersebut dapat berbentuk harta benda, seperti barang dagangan, benda bukan harta, seperti akad dalam pernikahan, dan dapat pula berbentuk suatu kemanfaatan, seperti dalam masalah upah-mengupah, dan lain-lain. ${ }^{8}$

Ma'qud 'alaih menurut mayoritas ulama hanafi termasuk benda yang berlawanan yang mempunyai arti yang berbeda. Ma'qud 'alaih adalah sesuatu yang bisa ditentukan wujudnya. ${ }^{9}$ Kaidah umum ini bisa saja berubah karena adanya faktor-faktor tertentu. Dengan demikian ma'qud 'alaih merupakan sesuatu yang tidak bisa ditentukan wujudnya bisa saja menjadi barang, seperti barang yang menjadi objek jual beli salam. Begitu pula, sesuatu yang bisa ditentukan wujudnya seperti modal yang diserahkan pada saat transaksi jual beli salam, apabila ia berupa barang yang berwujud. ${ }^{10}$

Barang yang dapat dimanfaatkan tentunya sangat relatif. Sebab pada hakikatnya seluruh barang yang dijadikan sebagai objek jual beli merupakan barang yang dapat dimanfaatkan, seperti untuk dikonsumsi. Contohnya beras, buah-buahan, ikan, sayur-mayur dan lainlain. Dinikmati keindahannya seperti hiasan rumah, bunga-bunga dan lain-lain. Dinikmati suaranya seperti radio, televisi, dan lain-lain serta dipergunakan untuk keperluan yang bermanfaat seperti membeli seekor anjing untuk berburu.

Pemanfaatan barang tersebut harus sesuai dengan ketentuan hukum agama syari'ah Islam, maksudnya pemanfaatan barang tersebut tidak boleh bertentangan dengan norma-norma agama yang ada. Misalnya sesuatu barang dibeli, yang tujuan pemanfaatan barang untuk berbuat yang bertentangan dengan syari'ah agama Islam atau berbuat yang dilarang, maka dapat dikatakan bahwa barang yang demikian tidak bermanfaat, ${ }^{11}$ Sabda Rasullulah SAW.

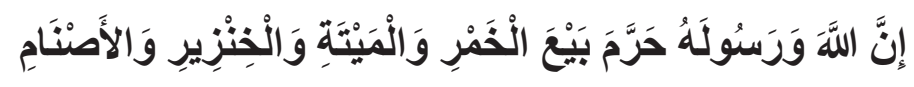

Artinya : Sesungguhnya Allah dan Rasul-Nya mengharamkan jual beli khamar, bangkai, babi dan patung. (HR. Bukhari dan Muslim). ${ }^{12}$

Barang yang memiliki kesamaan dengan barang lain, jika diukur dengan uang tunai maka ia berstatus barang, seperti barang yang serupa. Terkadang berupa barang yang bisa ditimbang, artinya dijual dengan menggunakan timbangan, seperti ikan dan semua jenis yang serupa. ${ }^{13}$ Disamping bentuk, zat, sifat dan kadarnya harus jelas. Barang yang diperjual belikan harus merupakan milik sendiri, dan sudah dimiliki sebagai milik yang sempurna (milk at-tamm), karena tidaklah diperbolehkan seseorang menjual sesuatu kecuali milik sendiri.

Ma'qud 'alaih merupakan barang yang dijadikan akad jual beli harus jelas baik bentuk,

Wahbah Az-Zuhaili, Fiqh Islam Wa Adillatuhu (Gema Insani 2011), hlm. 34.

Abdul Rahman Ghazaly, Fiqh Muamalat (Kencana 2010), hlm. 75.

Yusuf al-Qardhawi, Al-Furuuq, Juz 4, (Gema Insani Press 1997), hlm. 7.

Az-Zuhaili (n 7), hlm. 74.

Chairuman Pasaribu \& Suhrawardi, Hukum Perjanjian Islam (Sinar Grafika 1994), hlm. 38.

Muhammad Fu'ad Abdul Baqi, Hadits Shahih Bukhari Muslim (Pustaka Hikmah), hlm. 230.

Syekh Mustafa Az-Zarqa, 'Aqdul Bai (Dar-al-Qalam 1990), hlm. 50. 
kadar dan zat supaya tidak mengakibatkan keraguan pada pihak pembeli. Dalam hukum Islam jual beli barang tersebut harus jelas bentuk, kadar dan zatnya, jual beli suatu barang tidak sah apabila kadar atau beratnya masih belum jelas secara hakiki. ${ }^{14}$

Dalam sistem bisnis atau perdagangan yang sederhana, alat timbangan atau takaran memiliki peranan penting sebagai alat bagi keberlangsungan suatu transaksi antara penjual barang atau pembeli, yang barang tersebut bersifat material. Dalam perjalanannya untuk mendukung sistem ini kemudian dikenal ukuran-ukuran tertentu seperti ukuran berat jenis dari ons, kilogram hingga ton dan takaran literan. ${ }^{15}$

Taradhin merupakan salah satu asas fiqh mu'amalah. Ia berarti saling merelakan atau suka sama suka. Kerelaan bisa berupa kerelaan melakukan suatu bentuk muamalah atau kerelaan dalam menerima atau menyerahkan harta yang menjadi obyek perikatan, serta bentuk muamalah lainnya. Salah satu perasyaratan keabsahan transaksi bermuamalah di anatara para pihak yang terlibat. ${ }^{16}$ Demikian pula sesuai hadits Nabi saw :

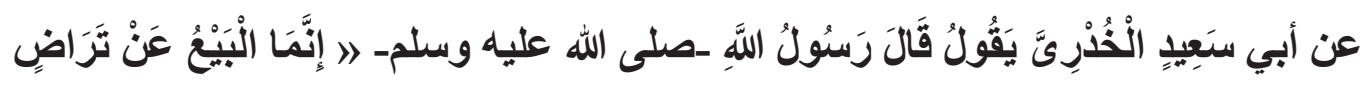

Artinya: Dari Abu Said Al-Khudri, Rasulullah shallallahu 'alaihi wa sallam bersabda, "Yang namanya jual beli itu hanyalah jika didasari asas saling rela." (HR. Ibnu Majah, no. 2269; dinilai sahih oleh Al-Albani).

\section{Proses Penimbangan}

Proses penimbangan ikan dilakukan dengan tujuan untuk mengetahui berapa berat ikan yang akan diproses. Penimbangan dilakukan dengan cara menimbang ikan dalam wadah. Penimbangan ini dilakukan dengan menggunakan timbangan digital. Tujuan penimbangan yaitu untuk mengetahui berat ikan yang akan di peroleh dari hasil tangkapan

Setelah ikan diterima ditempat penerimaan ikan, maka selanjutnya ikan akan ditimbang untuk mengetahui berat ikan tersebut. Pada proses ini banyak kekurangan takaran timbangan yang disebabkan oleh para pedagang ikan yang menimbangan ikan tampat memperhatiakan takaran timbangan. Sehinga tidak pas ukuran timbangan dan sering terjadi pembulatan ukuran timbangan ketika pembelian dalam jumlah yang besar. Cara menimbang ikan yang di lakukan oleh para pedagang ikan sebagai berikut:

1. Ikan setelah diterima penjual, kemudian dilakukan penimbangan untuk mengetahui kadar berat ikan.

2. Wadah tempat penimbangan tidak ditimbang ulang untuk mengetahui beratnya. Sebabkan berbeda wadah basah dengan kering, akan tetapi pihak pedagan mengukur nya sama semua dengan mengatakan berat wadah nya 3 kilogram.

3. Pada saat ditimbang ikan yang sudah diletakan dalam wadah di atas timbangan disirami air, kemudian baru di timbangan sehingga berat ikannya bertambah.

14 Rachmat Syafei, Fiqih Muamalah (Pustaka Setia 2000), hlm. 61, lihat juga Syaifullah MS, 'Etika Jual Beli Dalam Islam'; Shobirin Shobirin, 'Jual Beli Dalam Pandangan Islam' (2016) 3 BISNIS : Jurnal Bisnis dan Manajemen Islam 239 <http://journal.stainkudus.ac.id/index.php/Bisnis/article/view/1494>.

15 Diskusi tentang alat ukur dalam transaksi jual beli dapat merujuk Saprida Saprida, 'Tinjauan Fiqh Muamalah Terhadap Timbangan Jual Beli Karet Di Desa Betung Kecamatan Lubuk Keliat Kabupaten Ogan Ilir' (2017) 3 Islamic Banking : Jurnal Pemikiran dan Pengembangan Perbankan Syariah 11 <http://ejournal.stebisigm.ac.id/index.php/isbank/article/view/73>.

16 Untuk melihat asas-asas dasar dalam kajian fiqh muamalah, sila rujuk kajian Jamaluddin Jamaluddin, 'Konsep Dasar Muamalah \&amp; Etika Jual Beli (Al-Ba'i) Perspektif Islam' (2017) 28 Jurnal Pemikiran Keislaman 289 <https://ejournal.iai-tribakti.ac.id/index.php/tribakti/article/view/485>; Mualimin Mochammad Sahid and Mohammad Zaharuddin bin Mohamed, Mohd Faisal Zakaria, 'Rukun-Rukun Al-Bay’ Dan Al-Ijarah Dalam Kitab Sullam Al-Mubtadi Karangan Syeikh Daud Al-Fatani : Analisis Dari Perspektif Maqasid Al-Syariah' [2017] Malaysian Journal of Syariah and Law. 
4. Setelah ditimbang kemudian baru pihak penjual dan pembeli melakukan transaksi jual beli ikan tersebut.

Tabel. 2 Penimbangan ikan

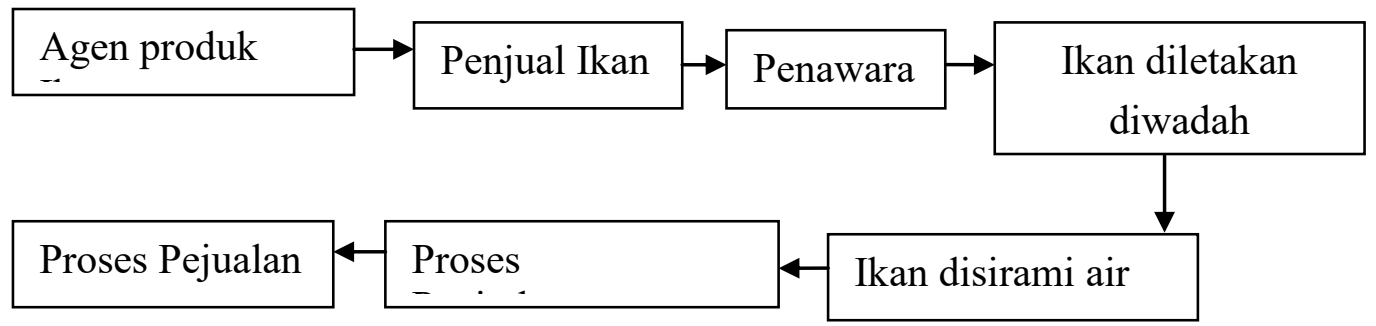

Proses Penimbangan Ikan di TPI Lampulo Banda Aceh. Sumber Observasi

\section{KESIMPULAN}

Proses penimbangan ikan di TPI Lampulo Banda Aceh dilakukan dengan tujuan untuk mengetahui berapa berat ikan yang diproses. Penimbangan ini dilakukan dengan menggunakan timbangan digital, tiimbangan duduk, dan timbangan gantung. Penimbangan dilakukan dengan cara menimbang ikan dalam wadah. Wadah tempat penimbangan tidak ditimbang ulang untuk mengetahui beratnya. Sebabkan berbeda wadah basah dengan kering, akan tetapi pihak pedagan mengukur nya sama semua dengan mengatakan berat wadah nya 3 kilogram. Pada saat ditimbang ikan yang sudah diletakan dalam wadah di atas timbangan disirami air, kemudian baru di timbangan sehingga berat ikannya bertambah.

Proses penimbangan ikan di TPI Lampulo Banda Aceh menurut perspektif Ma'qud 'alaih, belum akurat takaran timbangan, para pedagang kurang memperhatikan keakuratan timbangan dengan jelas, sehingga timbangan tidak akurat. Konsumen sering merasa dirugikan oleh pedagang, yang menjual ikan dengan jumlah yang besar, tidak memperhatikan wadah tempat penimbangan ikan kadang basah atau kering. Wadah berupa tempat penimbangan pada dasarnya beratnya hanya mencapai 2,8 kilogram, dan ketika wadah tersebut basah maka akan mencapai 3 kilogram, sehingga para pedagang langsung melakukan penimbangan tampat memperhatikan wadah tersebut, pedagang membulatkan berat wadah mencapai 3 kilogram dan sudah menjadi kebiasaan di TPI Lampulo Banda Aceh. Sehingga ketika konsumen membeli dalam jumlah yang besar maka akan mengalami kerugian sebesar 0.2 dalam setiap 1 kilogram. Maka sangat banyak kerugian yang diterima oleh konsumen ketika membeli dalam jumlah yang besar.

\section{DAFTAR PUSTAKA}

Abdul Rahman Ghazaly, Fiqh Muamalat (Kencana 2010)

Az-Zuhaili W, Fiqh Islam Wa Adillatuhu (Gema Insani 2011)

Chairuman Pasaribu \& Suhrawardi, Hukum Perjanjian Islam (Sinar Grafika 1994)

'Hasil Wawancara Dengan Nurdin, Pedagang Ikan Di TPI Lampulo Banda Aceh Pada Tangal 20 November 2017'

'Hasil Wawancara Dengan Ridwan, Pedagang Ikan Di TPI Lampulo Banda Aceh Pada Tangal 20 November 2017'

'Hasil Wawancara Dengan Saifudin Dan Samsul, Pedagang Ikan Di TPI Lampulo Banda Aceh Pada Tangal 20 November 2017' 
J. Moleong, Metodelogi Penelitian Kualitatif (PT Remaja Rosdakarya 2006)

Jamaluddin J, 'Konsep Dasar Muamalah \&amp; Etika Jual Beli (Al-Ba'i) Perspektif Islam' (2017) 28 Jurnal Pemikiran Keislaman 289 <https://ejournal.iai-tribakti.ac.id/ index.php/tribakti/article/view/485>

MS S, 'Etika Jual Beli Dalam Islam’

Muhammad Fu'ad Abdul Baqi, Hadits Shahih Bukhari Muslim (Pustaka Hikmah)

Rachmat Syafei, Fiqih Muamalah (Pustaka Setia 2000)

Sahid MM and bin Mohamed, Mohd Faisal Zakaria MZ, 'Rukun-Rukun Al-Bay' Dan AlIjarah Dalam Kitab Sullam Al-Mubtadi Karangan Syeikh Daud Al-Fatani : Analisis Dari Perspektif Maqasid Al-Syariah' [2017] Malaysian Journal of Syariah and Law

Saprida S, 'Tinjauan Fiqh Muamalah Terhadap Timbangan Jual Beli Karet Di Desa Betung Kecamatan Lubuk Keliat Kabupaten Ogan Ilir' (2017) 3 Islamic Banking: Jurnal Pemikiran dan Pengembangan Perbankan Syariah $11<$ http://ejournal.stebisigm. ac.id/index.php/isbank/article/view/73>

Shobirin S, 'Jual Beli Dalam Pandangan Islam' (2016) 3 BISNIS: Jurnal Bisnis dan Manajemen Islam 239 <http://journal.stainkudus.ac.id/index.php/Bisnis/article/ view/1494>

Syekh Mustafa Az-Zarqa, 'Aqdul Bai (Dar-al-Qalam 1990)

Yusuf al-Qardhawi, Al-Furuuq (Gema Insani Press 1997)

——, Norma Dan Etika Ekonomi Islam (Gema Insani Press 1997) 